Filol. Linguíst. Port., São Paulo, v. 16, n. spe, p. 11-13, dez. 2014 http://dx.doi.org/10.11606/issn.2176-9419.v16ispep11-13

\title{
Sobre a homenageada Charlotte Marie Chambelland Galves
}

A homenageada deste volume, Charlotte Galves, embora francesa de origem, é uma das maiores especialistas na gramática do português, tanto do ponto de vista sincrônico quanto diacrônico, e extremamente interessada nos aspectos que diferenciam as duas variedades principais desta língua, o Português Europeu (PE) e o Português Brasileiro (PB).

Seu interesse pelo português começou ainda na graduação, cursada na França, onde obteve o Bacharelado em Letras Clássicas e em Português. Seu trabalho continuou com um Mestrado em Português, obtido na Université de Paris III (Sorbonne-Nouvelle), em 1975, e com um Doutorado em Língua Portuguesa, obtido na Université de Paris IV (Paris-Sorbonne), em 1980.

Tendo estado primeiro em Portugal, chegou ao Brasil falando a língua fluentemente com forte sotaque português, o que a identificava, muitas vezes, como portuguesa, e não como francesa. Sua curiosidade sobre a nova variedade logo se manifestou na sintaxe, tendo seus primeiros trabalhos, aqui no Brasil, desvendado aspectos sintáticos não explorados pelos próprios linguistas brasileiros. São trabalhos seminais, entre outros, os seus artigos sobre o objeto nulo e sobre o sujeito nulo arbitrário, tópicos que vêm intrigando os linguistas desde então.

A carreira acadêmica da professora Charlotte pode ser dita exemplar, tanto em docência, quanto em dedicação a atividades administrativas, mas, sobretudo, em pesquisa científica, em torno da qual as demais atividades parecem também girar. Apenas para ilustrar, entre as suas atividades docentes, Charlotte formou 19 doutores e 24 mestres, além de ter orientado atividades de iniciação científica de vários alunos de graduação e recebido vários linguistas em estudos de pós-doutorado. No nível administrativo, a homenageada ocupou quase todos os cargos importantes, tais como chefia de departamento, coordenadora de cursos e diretora de instituto, além de ter sido membro em todos os colegiados.

No que diz respeito à pesquisa, passaremos a relatar alguns índices numéricos da sua produção científica para depois descrever a natureza de seus projetos. 
Seu curriculum Lattes mostra uma produção invejável, com um total de 31 artigos em periódicos nacionais e internacionais, 10 livros de sua autoria ou por ela editados, além de 29 artigos escritos como capítulos de livros e 12 textos em anais de congressos. Sua participação em eventos científicos nacionais e internacionais é atestada, com frequência, desde o início de sua carreira. O reconhecimento de Charlotte como pesquisadora aparece também nas suas funções como membro de conselhos editorias e nos seus trabalhos técnicos de parecerista ad hoc. Ocupou ainda o importante cargo de assessora da FAPESP na área de Letras, durante vários anos.

Quanto à sua pesquisa, três linhas se destacam: a) descrição e análise das línguas naturais, b) história da língua portuguesa e c) descrição e análise de padrões prosódicos.

Dentro da primeira área, como foi mencionado anteriormente, a prioridade foi a comparação sintática do $\mathrm{PE}$ com o PB, tendo seus artigos sido referência na descrição do Português Brasileiro para aqueles que seguem a perspectiva gerativa. Nessa linha, orientou ainda teses e dissertaçôes sobre línguas indígenas, sobre o latim e outras línguas românicas. Participou ainda do Projeto da Gramática do Português Falado, sob a coordenação geral de Ataliba de Castilho, tendo trabalhado no subprojeto das Relaçôes Gramaticais do corpus NURC, sub-coordenado, em fases distintas, por Fernando Tarallo, por ela, Mary Kato e Milton do Nascimento.

$\mathrm{Na}$ década de oitenta, aliou-se a Fernando Tarallo e Mary Kato para iniciar um projeto informal de linguística histórica, na UNICAMP, aliando a teoria gerativa com a metodologia variacionista. $\mathrm{O}$ grupo forma a primeira geração de linguistas históricos, que procura utilizar a teoria de Princípios e Parâmetros, com base em um corpus empírico com tratamento estatístico.

Com o falecimento de Fernando Tarallo e a aposentadoria de Mary Kato, Charlotte passa a coordenar projetos diacrônicos de interface sintaxe/prosódia e a trabalhar interdisciplinarmente com matemáticos e linguistas, não apenas do Brasil, mas também da Europa e dos Estados Unidos.

Nesse cenário, desenvolve a hipótese de que a mudança na ordem clíticoverbo, que ocorreu entre o Português Clássico e o Português Europeu, foi devida a uma mudança prosódica na língua. A ligação inovadora entre sintaxe e prosódia em estudos diacrônicos foi a base teórica e metodológica do projeto Padróes rítmicos, fixação de parâmetros e mudança linguistica que Charlotte iniciou com o suporte da Fundação de Amparo à Pesquisa do Estado de São Paulo (FAPESP). Sob a sua liderança, um programa rico de pesquisas diacrônicas em fonologia e sintaxe se estendeu por vários anos e por várias fases.

$\mathrm{O}$ alcance internacional deste projeto levou, entre outras coisas, a um trabalho colaborativo de longo termo, entre Charlotte e Anthony Kroch, na construção 
de um corpus histórico do Português Europeu, etiquetado sintaticamente. O corpus criado sob a supervisão de Charlotte na UNICAMP, o Tycho Brahe, foi um dos primeiros tipos de corpus dessa natureza no país, destinado ao uso específico de pesquisa sintática, tendo sido a base para muitos dos trabalhos de Charlotte, seus colegas e estudantes. O fato de ela ter disponibilizado esse corpus na web tem possibilitado o seu uso por vários pesquisadores no país e fora do Brasil.

Entre os resultados diacrônicos obtidos através do Tycho Brahe, um que merece atenção especial é a descoberta de que a colocação dos clíticos em Padre Vieira difere em frequência conforme o texto seja um sermão ou uma carta. Essa diferença levou Charlotte a mostrar como a prosódia da topicalização contrastiva interagia com a sintaxe da frase no Português Clássico, afetando a colocação dos clíticos. Uma consequência adicional desta descoberta foi a demonstração de que a mesma ordem verbo-clítico tinha uma causa diferente no Português Clássico e no Português Europeu Moderno, uma descoberta que auxilia na fixação da data de transição entre esses dois estágios da língua.

O sucesso do uso do corpus Tycho Brahe com o Português Clássico e Europeu Moderno levou Charlotte a estender, mais recentemente, o uso da mesma metodologia para projetos que documentem também a evolução da língua portuguesa no Brasil.

Por esta razão, este volume, que reúne trabalhos feitos por alguns de seus ex-orientandos de iniciação científica, mestrado e doutorado e pós-doutorandos, é uma merecida homenagem em reconhecimento à dedicação e à produção de Charlotte Galves.

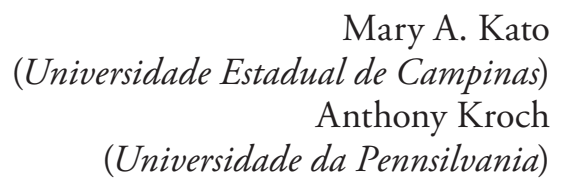

